\title{
Growth Responses and Photosynthetic Indices of Bamboo Plant (Indocalamus latifolius) under Heavy Metal Stress
}

\author{
Abolghassem Emamverdian $(\mathbb{D}),{ }^{1,2}$ Yulong Ding $\left(\mathbb{D},{ }^{1,3}\right.$ Farzad Mokhberdoran $(\mathbb{D}), 4$ \\ and Yinfeng Xie ${ }^{1,2}$ \\ ${ }^{1}$ Co-Innovation Center for Sustainable Forestry in Southern China, Nanjing Forestry University, Nanjing 210037, China \\ ${ }^{2}$ College of Biology and the Environment, Nanjing Forestry University, Nanjing 210037, China \\ ${ }^{3}$ Bamboo Research Institute, Nanjing Forestry University, Nanjing 210037, China \\ ${ }^{4}$ Department of Agronomy and Plant Breeding, Faculty of Agriculture, Islamic Azad University, \\ Mashhad Branch, Mashhad 94531, Iran
}

Correspondence should be addressed to Yulong Ding; ylding@vip.163.com

Received 17 May 2018; Accepted 8 July 2018; Published 15 July 2018

Academic Editor: Zhenli He

Copyright (C) 2018 Abolghassem Emamverdian et al. This is an open access article distributed under the Creative Commons Attribution License, which permits unrestricted use, distribution, and reproduction in any medium, provided the original work is properly cited.

\begin{abstract}
Investigating factors involved in the alleviation of the toxic effects of heavy metals (HMs) on plants is regarded as one of the important research concerns in the environmental field. The southern regions of China are severely impacted by human-induced heavy metal (HM) contamination, which poses an impediment to growth and productivity of bamboo (Indocalamus latifolius) plants. This necessitates the investigation of the effects of HMs on growth and physiological properties of bamboo. Therefore, the aim of the study was to evaluate some gas exchange and growth parameters in two-year-old bamboo species under HMs stress. A greenhouse-based experiment was conducted at Nanjing Forestry University, where the bamboo plant was treated with three HMs $(\mathrm{Cu}, \mathrm{Pb}$, and $\mathrm{Zn})$ at four different concentrations $(0,500,1000$, and $2000 \mathrm{mg} \mathrm{kg}-1)$. The results illustrated that excessive HMs (1000 and $2000 \mathrm{mg} \mathrm{kg}^{-1}$ ) triggered a decline in a number of photosynthetic-related indices including the rate of photosynthesis ( $\mu \mathrm{mol}$ $\left.\mathrm{CO}_{2} \mathrm{~m}^{-2} \mathrm{~s}^{-1}\right)$, intercellular $\mathrm{CO}_{2}$ concentration $\left(\mu \mathrm{mol} \mathrm{CO} \mathrm{Col}^{-1}\right)$, conductance to $\mathrm{H}_{2} \mathrm{O}\left(\mathrm{mol} \mathrm{H}_{2} \mathrm{O} \mathrm{m}^{-2} \mathrm{~s}^{-1}\right)$, and net assimilation as well as transpiration. Morphological indices were also depressed as a result of the adverse influence of HMs, leading to decreased shoot length (10 to $73 \%$ ) and reduced number of emerged plants (6 to 57\%). Also, the results indicated that $\mathrm{Pb}$ had the greatest harmful impact on the growth indices.
\end{abstract}

\section{Introduction}

The excessive levels of heavy metals (HMs) in the soil, which mainly stem from human-induced activities, are a major threat to human health, plant productivity, and wildlife [1, 2]. HMs are viewed as one of the chief culprits for the contaminated human and animal food chains. They can accumulate in plant organs and act as a growth inhibitor by disrupting plant vital physiological and developmental processes $[3,4]$. When found in trace amounts in soil, some metals such as $\mathrm{Cu}$ and $\mathrm{Zn}$ have positive effects on plant growth. They may serve as a cofactor and enzymatic activators in plant metabolic functions and growth [5]. But there are also some nonessential metals including $(\mathrm{Cr}, \mathrm{Cd}$,
$\mathrm{Pb}, \mathrm{Hg}$, and $\mathrm{Cl}$ ) that even in small quantities can exert deleterious impacts on plant growth and development [6]. The extreme concentration of metals in the soil can bring about detrimental changes to plant photosynthesis, eventually leading to the reduction of plant growth and yield [7]. Moreover, they are capable of causing oxidative stress in plants via generating, e.g., "Reactive Oxygen Species (ROS)" [8]. Heavy metals can indirectly impact plants by disrupting electron transport chain and superseding essential elements [9]. Their adverse influence on plant gas exchange attributes includes cellular water imbalance, decreased photosynthetic pigments, reduced $\mathrm{CO}_{2}$ assimilation and chlorophyll content, and inopportune stomatal closure [10]. Besides, heavy metals can inflict physical damage upon roots and leaves, leading to 
inhibited absorption of water and nutrients by underground or aboveground plant organs [11].

Bamboo plants cover large parts of China forests $[12,13]$. There are 500 species at 48 genera of bamboo in China $[14,15]$. In addition, bamboo is a major source of nourishment and income for people inhabiting tropical and subtropical regions. Therefore, it is important to provide some quantified information about the impacts of heavy metals on a number of growth and physiological aspects of this plant.

The objective of the study was to investigate some gas exchange parameters and growth indices in two-year-old bamboo species (Indocalamus latifolius) under heavy metal stress. Another aim pursued in the study was to find out if HMs in low concentrations contributed positively to the growth parameters of the bamboo plant.

\section{Materials and Methods}

2.1. Experimental Design and Statistical Analysis. The experiment was conducted in a completely randomized block design (CRBD) with five replications at Nanjing Forestry University greenhouse to evaluate the effects of three types of the most prevalent heavy metals found in southern area of China including $(\mathrm{Cu}, \mathrm{Pb}$, and $\mathrm{Zn})$ at four different rates: 0,500 , 1000 , and $2000 \mathrm{mg} \mathrm{kg-1}$ on a two-year-old bamboo species (Indocalamus latifolius). Analysis of variance (ANOVA) test was computed using statistical software package $\mathrm{R}$. The difference between means was compared by Tukey's test at the $\mathrm{P}>0.05$ confidence level. Vertical bars in the figures indicate standard deviation (SD).

For the preexperiment stage, the two-year-old bamboo species were subjected to different concentrations of heavy metals in the spring for a period of 60 days. The specific amounts of heavy metals during the experiment period were summarized in Table 1.

\subsection{Photosynthetic Parameters. Photosynthetic-related} parameters including net photosynthetic rate $(\mathrm{PN})$, conductance to $\mathrm{H}_{2} \mathrm{O}$ (Cond), intercellular $\mathrm{CO}_{2}$ concentration (Ci), and transpiration rate ( $\mathrm{Tr}$ ) were quantified using the LI-6400XT Portable Photosynthesis System (LI-COR, Lincoln, Nebraska, USA). The device is fitted with blue and red LEDs (LI-6400-02B) as a light source for the relevant photosynthetic measurements. All the leaf gas exchange properties were recorded under the sample chamber condition where photosynthetic photon flux density (PPFD) was at $1000 \mu \mathrm{Mm}^{-2} \mathrm{~s}^{-1}$, leaf temperature was at $25^{\circ} \mathrm{C}$, and the $\mathrm{CO}_{2}$ level was at $380 \mu \mathrm{M} \mathrm{CO} \mathrm{mol}^{-1}$.

2.3. Growth Indices. Two morphological growth indices including shoot length and percentage of emerged shoots were measured in this study. To record shoot length, the heights of 3 to 4 of the tallest shoots in each pot were manually measured before and after the exposure of the bamboo plant to HMs stress. To determine the percentage of the emerged shoots, the number of shoots per pot was counted prior to the application of the treatments and at the end of the experiment, the difference between the initial number of shoots and surviving ones per pot/treatment was computed. Both measurements were expressed in percentage terms.

\section{Results}

3.1. Gas Exchange Properties (Photosynthetic Parameters). Photosynthetic measurements revealed that high concentrations of HMs had a negative impact on the bamboo gas exchange parameters, particularly at the elevated levels (1000-2000 (mg/ $\left.\left.\mathrm{kg}^{-1}\right)\right)$, which led to a significant reduction in the photosynthetic indices including PN, Cond, Ci, and Tr. As demonstrated in Table 2, but they increased at low levels $\left(500 \mathrm{mg} / \mathrm{kg}^{-1}\right)$ of $\mathrm{Cu}$ and $\mathrm{Zn}$. All the measured photosynthetic properties decreased at high HMs concentrations so that the HMs treatments, when applied at extreme concentrations, caused a larger decline of photosynthetic properties compared to lower levels of HMs. Overall, photosynthetic properties decreased by approximately 1.15-, 1.46-, and 1.12fold of the control under the $\mathrm{Cu}, \mathrm{Pb}$, and $\mathrm{Zn}$ treatments, respectively. This shows that $\mathrm{Pb}$ resulted in the greatest reduction in photosynthetic indices, whereas $\mathrm{Zn}$ caused the lowest reduction. Moreover, across the HMs concentrations tested, $2000 \mathrm{mg} / \mathrm{kg}^{-1}$ application rate was found to exert the most pernicious impact on photosynthetic processes and $500 \mathrm{mg} / \mathrm{kg}^{-1}$ level was the concentration that caused the smallest decline in the photosynthetic parameters (under the influence of lead).

3.2. Effects of $\mathrm{Cu}, \mathrm{Pb}$, and $\mathrm{Zn}$ on the Growth Parameters. Our results indicated that the lowest concentration of HMs (500 $\mathrm{mg} \mathrm{kg}{ }^{-1}$ ) positively contributed to the growth of bamboo species, but there was a significant reduction in the plant growth indices (shoot height and the number of emerged shoots), when HMs levels were further increased to 1000 and $2000 \mathrm{mg} \mathrm{kg}^{-1}$. The application of $\mathrm{Cu}$ led to an $11 \%$ increase at $500 \mathrm{mg} / \mathrm{kg}^{-1}$ and a $33 \%$ decline in growth parameters at 1000 and $2000 \mathrm{mg} / \mathrm{kg}^{-1}$. The growth parameters were increased by $4 \%$ and decreased by $40 \%$ under the 1000 and $2000 \mathrm{mg} / \mathrm{kg}^{-1}$ $\mathrm{Pb}$ treatments, respectively. Zinc caused a $12 \%$ increase at $1000 \mathrm{mg} / \mathrm{kg}^{-1}$ and a $23 \%$ increase at $2000 \mathrm{mg} / \mathrm{kg}^{-1}$ in growth relative to the control (Figure 1).

Shoot height measurements indicated that the low concentration of HMs encouraged the growth of shoot length. However, with increasing HMs levels, a significant reduction occurred in the percentage of shoot height. $\mathrm{Cu}, \mathrm{Pb}$, and Zn produced about 1.11-, 1.04-, and 1.18-fold increase in the shoot length over the control at $500 \mathrm{mg} \mathrm{kg}^{-1}$ but caused approximately 1.35-, 1.45-, and 1.22-fold decrease over the control at $2000 \mathrm{mg} \mathrm{kg}^{-1}$, respectively (Table 2, Figure 1).

3.3. Effects of HMs on the Percentage of Emerged Plants. The results of mean comparison for the effects of HMs on the percentage of emerged bamboo plants revealed the same trend for this trait as for the shoot length percentage. According to the results, the percentage of the emerged plants was about 1.06-fold higher than the control at $\mathrm{Zn} 500 \mathrm{mg}$ $\mathrm{kg}^{-1}$, but it was about 1.31-, 1.35-, and 1.24-fold lower than the 
TABLE 1: HM concentrations in pots.

\begin{tabular}{lccc}
\hline HM concentrations & $500\left(\mathrm{mg} / \mathrm{kg}^{-1}\right)$ & $1000\left(\mathrm{mg} / \mathrm{kg}^{-1}\right)$ & $2000\left(\mathrm{mg} / \mathrm{kg}^{-1}\right)$ \\
\hline pots & $647 \mathrm{mg}$ & $1295 \mathrm{mg}$ & $2591 \mathrm{mg}$ \\
\hline
\end{tabular}

TABLE 2: Photosynthetic indices of Indocalamus latifolius as affected by HMs stress.

\begin{tabular}{|c|c|c|c|c|c|}
\hline \multirow{2}{*}{\multicolumn{2}{|c|}{ HM treatment }} & \multicolumn{4}{|c|}{ Photosynthetic indices } \\
\hline & & $\begin{array}{c}\mathrm{Pn} \\
\left(\mu \mathrm{mol} \mathrm{CO} \mathrm{CO}_{2} \mathrm{~m}^{-1}\right)\end{array}$ & $\begin{array}{c}\text { Cond } \\
\left(\mathrm{mol} \mathrm{H} 2 \mathrm{O} \mathrm{m}^{-2} \mathrm{~s}^{-1}\right)\end{array}$ & $\begin{array}{c}\mathrm{Ci} \\
\left(\mu \mathrm{mol} \mathrm{CO} \mathrm{mol}^{-1}\right)\end{array}$ & $\begin{array}{c}\mathrm{Tr} \\
\left(\mathrm{mmol} \mathrm{H}_{2} \mathrm{Om}^{-2} \mathrm{~s}^{-1}\right)\end{array}$ \\
\hline \multirow{4}{*}{$\begin{array}{l}\mathrm{Cu} \\
\left(\mathrm{mg} \mathrm{kg}^{-1}\right)\end{array}$} & 0 & $70.2 \pm 1.4^{\mathrm{Aa}}$ & $0.05 \pm 0.02^{\mathrm{Aa}}$ & $17.67 \pm 6.01^{\mathrm{ABa}}$ & $1.3 \pm 0.48^{\mathrm{ABa}}$ \\
\hline & 500 & $75.2 \pm 5.2^{\mathrm{Aa}}$ & $0.06 \pm 0.04^{\mathrm{Ab}}$ & $21.11 \pm 4.5^{\mathrm{Ab}}$ & $1.7 \pm 0.47^{\mathrm{Ab}}$ \\
\hline & 1000 & $63.4 \pm 2.5^{\mathrm{Ba}}$ & $0.03 \pm 0.007^{\mathrm{Aa}}$ & $11.02 \pm 3.9^{\mathrm{Bb}}$ & $1.1 \pm 0.20^{\mathrm{ABa}}$ \\
\hline & 2000 & $53.08 \pm 1.1^{\mathrm{Ca}}$ & $0.02 \pm 0.01^{\mathrm{Aa}}$ & $10.81 \pm 4.5^{\mathrm{Bb}}$ & $0.9 \pm 0.41^{\mathrm{Ba}}$ \\
\hline \multirow{4}{*}{$\mathrm{Pb}\left(\mathrm{mg} \mathrm{kg}^{-1}\right)$} & 0 & $73.6 \pm 3.06^{\mathrm{Aa}}$ & $0.14 \pm 0.04^{\mathrm{Aa}}$ & $35.93 \pm 5.8^{\mathrm{Aa}}$ & $2.7 \pm 0.13^{\mathrm{Aa}}$ \\
\hline & 500 & $65.6 \pm 1.4^{\mathrm{Bb}}$ & $0.07 \pm 0.04^{\mathrm{Ba}}$ & $19.51 \pm 6.1^{\mathrm{ABa}}$ & $1.3 \pm 0.25^{\mathrm{Ba}}$ \\
\hline & 1000 & $57.4 \pm 1.6^{\mathrm{Cb}}$ & $0.04 \pm 0.01^{\mathrm{Ba}}$ & $26.31 \pm 6.45^{\mathrm{Ba}}$ & $0.9 \pm 0.25^{\mathrm{BCa}}$ \\
\hline & 2000 & $48.7 \pm 1.2^{\mathrm{Db}}$ & $0.02 \pm 0.01^{\mathrm{Ba}}$ & $21.25 \pm 6.6^{\mathrm{Ba}}$ & $0.8 \pm 0.42^{\mathrm{Ca}}$ \\
\hline \multirow{4}{*}{$\begin{array}{l}\mathrm{Zn} \\
\left(\mathrm{mg} \mathrm{kg}^{-1}\right)\end{array}$} & 0 & $64.08 \pm 1.1^{\mathrm{Bb}}$ & $0.07 \pm 0.05^{\mathrm{Aa}}$ & $16.73 \pm 3.4^{\mathrm{Aa}}$ & $1.2 \pm 0.45^{\mathrm{ABa}}$ \\
\hline & 500 & $69.4 \pm 4.2^{\mathrm{Aa}}$ & $0.07 \pm 0.04^{\mathrm{Aab}}$ & $20.10 \pm 6.1^{\mathrm{Ab}}$ & $1.4 \pm 0.264^{\mathrm{Ab}}$ \\
\hline & 1000 & $58.7 \pm 1.9^{\mathrm{Cb}}$ & $0.05 \pm 0.04^{\mathrm{Aa}}$ & $16.14 \pm 8.1^{\mathrm{Aab}}$ & $0.9 \pm 0.20^{\mathrm{ABa}}$ \\
\hline & 2000 & $50.6 \pm 2.08^{\mathrm{Dab}}$ & $0.03 \pm 0.01^{\mathrm{Aa}}$ & $11.45 \pm 2.5^{\mathrm{Ab}}$ & $0.7 \pm 0.38^{\mathrm{Ba}}$ \\
\hline
\end{tabular}

control at Cu $500 \mathrm{mg} \mathrm{kg}^{-1}, \mathrm{~Pb} 1000 \mathrm{mg} \mathrm{kg}^{-1}$, and Zn $2000 \mathrm{mg}$ $\mathrm{kg}^{-1}$, respectively (Table 2, Figure 1).

\section{Discussion}

4.1. Effects of $\mathrm{Cu}, \mathrm{Zn}$, and $\mathrm{Pb}$ on Photosynthetic Parameters. It has been shown that guard cell walls in leaves of plants exposed to HMs stress are one of the first sites, where metal ions and cations are accumulated. This can result in the production of $\mathrm{H}_{2} \mathrm{O}_{2}$ in leaf tissues [16]. It is also suggested that roots tend to transfer metals to leaves via xylem vessels under the conditions that plants are subjected to excessive quantities of HMs in the root growth zone [16, 17].

HMs often directly impinge on the structure of thylakoid membranes at chloroplast site and also on photosynthetic proteins, which thereby perniciously affect the efficiency of photochemistry properties in dark-adapted leaves and photosystem II [18]. This leads to reduced energy transmission to the photosynthetic reaction centre [19]. Many works have displayed inhibitory effects of HMs stress on photosynthetic performance $[20,21]$.

Our findings suggested that almost all photosynthetic properties decreased with an excess of HMs (except $\mathrm{Cu}$ and $\mathrm{Zn}$ in $500 \mathrm{mg} / \mathrm{kg}^{-1}$ ). The results indicated that excessive quantities of HMs reduced the number of photosyntheticrelated indices including the rate of photosynthesis $(\mu \mathrm{mol}$ $\left.\mathrm{CO}_{2} \mathrm{~m}^{-2} \mathrm{~s}^{-1}\right)$, intercellular $\mathrm{CO}_{2}$ concentration $(\mu \mathrm{mol} \mathrm{CO}$ $\left.\mathrm{mol}^{-1}\right)$, conductance to $\mathrm{H}_{2} \mathrm{O}\left(\mathrm{mol} \mathrm{H}_{2} \mathrm{O} \mathrm{m}^{-2} \mathrm{~s}^{-1}\right)$, and net assimilation as well as transpiration. These observations are in line with the findings of Chen et al. (2011) [22], where they found that Cd stress decreased the net rate of photosynthesis (Pn) and stomatal conductance (Gs) in pak choi and mustard.
Similar observations are reported for sunflower and corn where net photosynthesis and transpiration were declined by HMs stress [23]. It is shown that dwindling photosynthetic rates in plants exposed to $\mathrm{Cu}$ excess mostly emanates from the closure of the stomatal apparatus [24].

4.2. Growth Indices. Our results showed that the growth indexes in bamboo species rose at the lowest HM concentration $\left(500 \mathrm{mg} / \mathrm{kg}^{-1}\right)$, which is suggestive of the protective role of antioxidant enzymes against mild HMs stress. In contrast, the extreme HMs levels (1000 and $2000 \mathrm{mg} / \mathrm{kg}^{-1}$ ) mainly led to a depressed growth in bamboo species as compared to the control (Table 3).

The observed decrease in shoot length might have occurred due to injurious effects of HMs on mesophyll cells in leaf and the stimulation of oxidative stress [25]. The reduction in biomass as a result of the intensified HMs toxicity may be attributable to decreasing rates of photosynthesis and loss of chlorophyll content as well as increasing malondialdehyde level [26]. Afshan et al. 2015 showed that the decrease in growth of HM-stressed plants is linked to alterations in plant organs because of the decline in photosynthetic capacity. They also confirmed that excess of $\mathrm{Cu}$ reduces growth indices in Brassica napus L. [27].

Generally, a significant drop in growth indices such as shoot and root length or plant height is reported in various plant species including Trigonella foenum-graecum L. grown under Cd stress [28], Jatropha curcas subjected to Pb excess [29], Glycyrrhiza uralensis seedlings exposed to Cd stress [30], tomato, canola, and Indian mustard seeds treated with $\mathrm{Pb}, \mathrm{Zn}$, and Ni excess [31], Vicia faba L. under Cd stress [32], and Arabidopsis thaliana under $\mathrm{Cu}, \mathrm{Mn}$, and $\mathrm{Zn}, \mathrm{Pb}$, and $\mathrm{Hg}$ stress [33]. 
TABLE 3: Effects of different concentrations of HMs on growth indices Indocalamus latifolius.

\begin{tabular}{|c|c|c|c|c|}
\hline \multirow{2}{*}{ HMs } & \multirow{2}{*}{ Growth indices } & \multicolumn{3}{|c|}{ Concentration } \\
\hline & & $500\left(\mathrm{mg} / \mathrm{kg}^{-1}\right)$ & $1000\left(\mathrm{mg} / \mathrm{kg}^{-1}\right)$ & $2000\left(\mathrm{mg} / \mathrm{kg}^{-1}\right)$ \\
\hline \multirow[b]{2}{*}{$\mathrm{Cu}$} & $\begin{array}{l}\text { Percentage of } \\
\text { shoot length }\end{array}$ & $11 \uparrow$ & $22 \downarrow$ & $47 \downarrow$ \\
\hline & $\begin{array}{c}\text { Percentage emerged } \\
\text { plants }\end{array}$ & $6 \downarrow$ & $30 \downarrow$ & $57 \downarrow$ \\
\hline \multirow[b]{2}{*}{$\mathrm{Pb}$} & $\begin{array}{l}\text { Percentage of } \\
\text { shoot length }\end{array}$ & $4 \uparrow$ & $17 \downarrow$ & $73 \downarrow$ \\
\hline & $\begin{array}{l}\text { Percentage of } \\
\text { emerged plants }\end{array}$ & $14 \downarrow$ & $25 \downarrow$ & $36 \downarrow$ \\
\hline \multirow[b]{2}{*}{$\mathrm{Zn}$} & $\begin{array}{l}\text { Percentage of } \\
\text { shoot length }\end{array}$ & $18 \uparrow$ & $10 \downarrow$ & $34 \downarrow$ \\
\hline & $\begin{array}{l}\text { Percentage of } \\
\text { emerged plants }\end{array}$ & $5 \uparrow$ & $17 \downarrow$ & $32 \downarrow$ \\
\hline
\end{tabular}

Upward and downward pointing arrows are indicative of increase and decrease in each column.
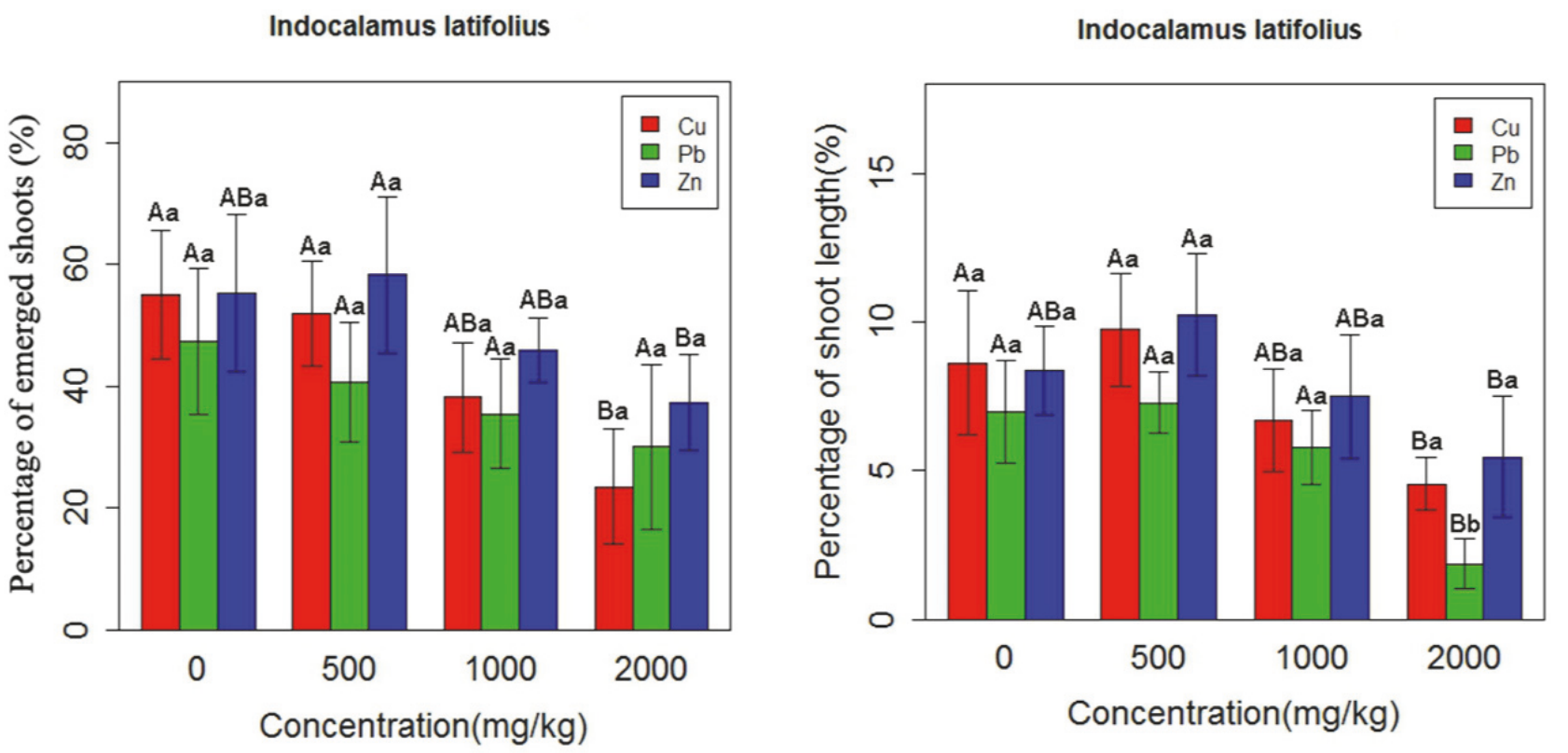

FIGURE 1: Effects of HMs on growth indices of Indocalamus latifolius. The capital letters are the demonstration of statistical significance between different heavy metals across various concentrations and the small letters are the demonstration of statistical significance between heavy metals in each concentration. Vertical bars represent \pm SD $(n=5)$.

These observations are in agreement with the results of our experiment, where it was revealed that HMs stress in high concentrations negatively affected the percentage of shoot length, resulting in decreased shoot length. Moreover, we found that the number of the emerged bamboo stands in the species used in our study was reduced when it was subjected to excessive amounts of HMs.

\section{Conclusions and Statements}

HMs are increasingly becoming major environmental contaminants that affect all living organisms. Bamboo plants are particularly exposed to this abiotic stressor in southern China, which makes it essential for researchers to conduct relevant studies to fully understand the pernicious effects of HMs on various biological and physiological aspects of bamboo. Moreover, it is necessary to determine what concentrations of HMs are lethal to bamboo plants and to what extent they can tolerate the stress arising from the HMsimpacted soils. Moreover, the assumption should be tested in bamboo plants whether or not HMs in low concentrations are beneficial to their growth and development.

The results of current work suggested that $\mathrm{Cu}, \mathrm{Pb}$, and $\mathrm{Zn}$ at low concentrations $\left(500 \mathrm{mg} \mathrm{kg}^{-1}\right)$ were associated with an increase in physiological activities and the stimulation of growth in Indocalamus latifolius. However, it was found that high concentrations of HMs (1000 and $2000 \mathrm{mg} \mathrm{kg}^{-1}$ ) resulted in a decline in the photosynthetic indices of the 
bamboo species and also had inhibitory effects on its growth. Besides, our results revealed that $\mathrm{Pb}$ had the greatest damaging impact on the gas exchange properties and growth indices in Indocalamus latifolius.

\section{Abbreviations \\ HMs: Heavy metals \\ ROS: Reactive oxygen species.}

\section{Data Availability}

The data used to support the findings of this study are available from the corresponding author upon request.

\section{Conflicts of Interest}

The authors declare that there are no conflicts of interest regarding the publication of this paper.

\section{Acknowledgments}

This work was supported by the Special Fund for Forest Scientific Research in the Public Welfare from State Forestry Administration of China [no. 201504106] and a project funded by the Priority Academic Program Development of Jiangsu Higher Education Institutions.

\section{References}

[1] S. K. Sethy and S. Ghosh, "Effect of heavy metals on germination of seeds," Journal of Natural Science, Biology and Medicine, vol. 4, no. 2, pp. 272-275, 2013.

[2] N. Bacaha, R. Shamas, J. Bakht, A. Rafi, Farhatullah, and A. Gillani, "Effect of heavy metal and EDTA application on plant growth and phyto-extraction potential of Sorghum (Sorghum bicolor)," Pakistan Journal of Botany, vol. 47, no. 5, pp. 16791684, 2015.

[3] A. Okem, M. Moyo, W. A. Stirk, J. F. Finnie, and J. Van Staden, "Investigating the effect of cadmium and aluminium on growth and stress-induced responses in the micropropagated medicinal plant Hypoxis hemerocallidea," Plant biology (Stuttgart, Germany), vol. 18, no. 5, pp. 805-815, 2016.

[4] S. Singh, P. Parihar, R. Singh, V. P. Singh, and S. M. Prasad, "Heavy Metal Tolerance in Plants: Role of Transcriptomics, Proteomics, Metabolomics, and Ionomics," Frontiers in Plant Science, vol. 6, 2016.

[5] R. K. Sharma and M. Agrawal, "Biological effects of heavy metals: An overview," Journal of Environmental Biology, vol. 26, pp. 301-313, 2005.

[6] P. U. Singare and M. P. Trivedi, Ravindra M., "Sediment Heavy Metal Contaminants in Vasai Creek Of Mumbai: Pollution Impacts," American Journal of Chemistry, vol. 2, no. 3, pp. 171180, 2012.

[7] G. U. Chibuike and S. C. Obiora, "Heavy Metal Polluted Soils: Effect on Plants and Bioremediation Methods," Applied and Environmental Soil Science, vol. 2014, pp. 1-12, 2014.
[8] E. Keunen, T. Remans, S. Bohler, J. Vangronsveld, and A. Cuypers, "Metal-induced oxidative stress and plant mitochondria," International Journal of Molecular Sciences, vol. 12, no. 10, pp. 6894-6918, 2011.

[9] S. K. Yadav, "Heavy metals toxicity in plants: an overview on the role of glutathione and phytochelatins in heavy metal stress tolerance of plants," South African Journal of Botany, vol. 76, no. 2, pp. 167-179, 2010.

[10] M. Mourato, I. Moreira, I. Leitão, F. Pinto, J. Sales, and L. Martins, "Effect of Heavy Metals in Plants of the Genus Brassica," International Journal of Molecular Sciences, vol. 16, no. 8, pp. 17975-17998, 2015.

[11] S. Cheng, "Effect of heavy metals on plants and resistance mechanism," Environmental Science and Pollution Research, vol. 10, pp. 256-264, 2003.

[12] W. Yan, Q. Mahmood, D. Peng et al., "The spatial distribution pattern of heavy metals and risk assessment of moso bamboo forestsoil around lead-zinc mine in Southeastern China," Soil \& Tillage Research, vol. 153, pp. 210-130, 2015.

[13] Z. Huang, S. Jin, H. Guo et al., "Genome-wide identification and characterization of TIFY familygenes in Moso Bamboo (Phyllostachys edulis) and expression profiling analysis underdehydration and cold stresses," PeerJ, vol. 4, p. e2620, 2016.

[14] Q. Yang, Z. Duan, Z. Wang, K. He, Q. Sun, and Z. Peng, "Bamboo resources, utilization and ex-situ conservation in Xishuangbanna, South-eastern China," Journal of Forestry Research, vol. 19, no. 1, pp. 79-83, 2008.

[15] Y.-P. Huang, C.-H. Hou, H.-C. Hsi, and J.-W. Wu, “Optimization of highly microporous activated carbon preparation from Moso bamboo using central composite design approach," Journal of the Taiwan Institute of Chemical Engineers, vol. 50, pp. 266-275, 2015.

[16] T. Lomaglio, M. Rocco, D. Trupiano et al., "Effect of short-term cadmium stress on Populus nigra L. detached leaves," Journal of Plant Physiology, vol. 182, pp. 40-48, 2015.

[17] F. Zhou, J. Wang, and N. Yang, "Growth responses, antioxidant enzyme activities and lead accumulation of Sophora japonica and Platycladus orientalis seedlings under $\mathrm{Pb}$ and water stress," Plant Growth Regulation, vol. 75, no. 1, pp. 383-389, 2014.

[18] Y.-E. Chen, J.-M. Cui, J.-C. Yang et al., "Biomonitoring heavy metal contaminations by moss visible parameters," Journal of Hazardous Materials, vol. 296, pp. 201-209, 2015.

[19] A. Dezhban, A. Shirvany, P. Attarod, M. Delshad, M. Matinizadeh, and M. Khoshnevis, "Cadmium and lead effects on chlorophyll fluorescence, chlorophyll pigments and proline of Robinia pseudoacacia," Journal of Forestry Research, vol. 26, no. 2, pp. 323-329, 2015.

[20] R. W. Santos, É. C. Schmidt, R. d. Martins et al., "Effects of Cadmium on Growth, Photosynthetic Pigments, Photosynthetic Performance, Biochemical Parameters and Structure of Chloroplasts in the Agarophyte Gracilaria domingensis (Rhodophyta, Gracilariales)," American Journal of Plant Sciences, vol. 03, no. 08, pp. 1077-1084, 2012.

[21] R. Chandra and H. Kang, "Mixed heavy metal stress on photosynthesis, transpiration rate, and chlorophyll content in poplar hybrids," Forest Science and Technology, vol. 12, no. 2, pp. 55-61, 2016.

[22] X. Chen, J. Wang, Y. Shi, M. Q. Zhao, and G. Y. Chi, "Effects of cadmium on growth and photosynthetic activities in pakchoi and mustard," Botanical Studies, vol. 52, no. 1, pp. 41-46, 2011.

[23] R. W. Carlson, F. A. Bazzaz, and G. L. Rolfe, "The effect of heavy metals on plants. II. Net photosynthesis and transpiration of 
whole corn and sunflower plants treated with $\mathrm{Pb}, \mathrm{Cd}, \mathrm{Ni}$, and Tl," Environmental Research, vol. 10, no. 1, pp. 113-120, 1975.

[24] N. Bazihizina, I. Colzi, E. Giorni, S. Mancuso, and C. Gonnelli, "Photosynthesizing on metal excess: Copper differently induced changes in various photosynthetic parameters in copper tolerant and sensitive Silene paradoxa L. populations," Journal of Plant Sciences, vol. 232, pp. 67-76, 2015.

[25] S. Ali, A. Chaudhary, M. Rizwan et al., "Alleviation of chromium toxicity by glycinebetaine is related to elevated antioxidant enzymes and suppressed chromium uptake and oxidative stress in wheat (Triticum aestivum L.)," Environmental Science and Pollution Research, vol. 22, no. 14, pp. 10669-10678, 2015.

[26] H. Terzi and M. Ylldiz, "Interactive effects of sulfur and chromium on antioxidative defense systems and BnMP1 gene expression in canola (Brassica napus L.) cultivars differing in Cr(VI) tolerance," Ecotoxicology, vol. 24, no. 5, pp. 1171-1182, 2015.

[27] S. Afshan, S. Ali, S. A. Bharwana et al., "Citric acid enhances the phytoextraction of chromium, plant growth, and photosynthesis by alleviating the oxidative damages in Brassica napus L.," Environmental Science and Pollution Research, vol. 22, no. 15, pp. 11679-11689, 2015.

[28] G. Bashri and S. M. Prasad, "Indole acetic acid modulates changes in growth, chlorophyll a fluorescence and antioxidant potential of Trigonella foenum-graecum L. grown under cadmium stress," Acta Physiologiae Plantarum, vol. 37, no. 3, 2015.

[29] X. Shu, L. Yin, Q. Zhang, and W. Wang, "Effect of Pb toxicity on leaf growth, antioxidant enzyme activities, and photosynthesis in cuttings and seedlings of Jatropha curcas L," Environmental Science and Pollution Research, vol. 19, no. 3, pp. 893-902, 2012.

[30] G. Zheng, H. P. Lv, S. Gao, and S. R. Wang, "Effects of cadmium on growth and antioxidant responses in glycyrrhiza uralensis seedlings," Plant Soil and Environment, vol. 56, no. 11, pp. 508$515,2010$.

[31] G. I. Burd, D. G. Dixon, and B. R. Glick, "Plant growthpromoting bacteria that decrease heavy metal toxicity in plants," Canadian Journal of Microbiology, vol. 46, no. 3, pp. 237-245, 2000.

[32] M. H. Siddiqui, M. H. Al-Whaibi, A. M. Sakran, M. O. Basalah, and H. M. Ali, "Effect of calcium and potassium on antioxidant system of Vicia faba L. under cadmium stress," International Journal of Molecular Sciences, vol. 13, no. 6, pp. 6604-6619, 2012.

[33] S. Baek, T. Han, S. Ahn et al., "Effects of Heavy Metals on Plant Growths and Pigment Contents in Arabidopsis thaliana," The Plant Pathology Journal, vol. 28, no. 4, pp. 446-452, 2012. 


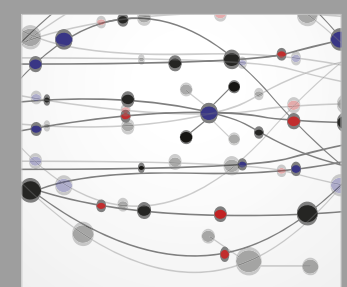

The Scientific World Journal
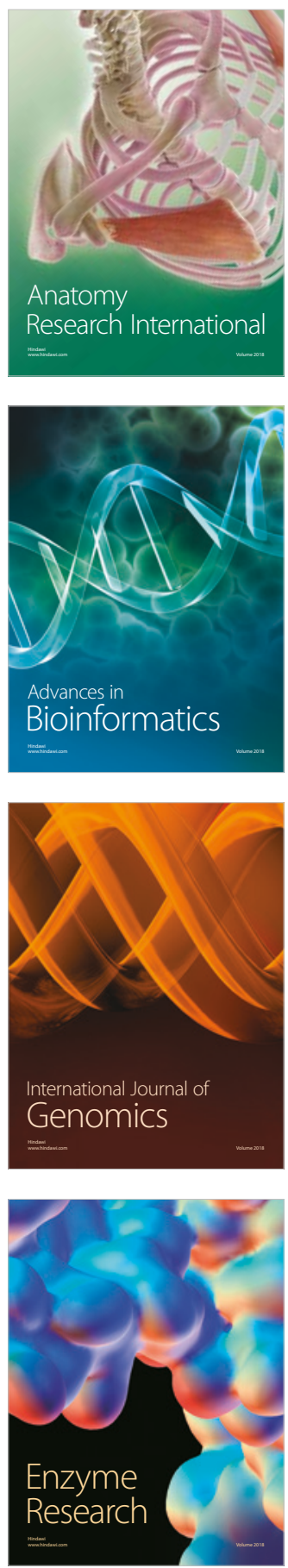
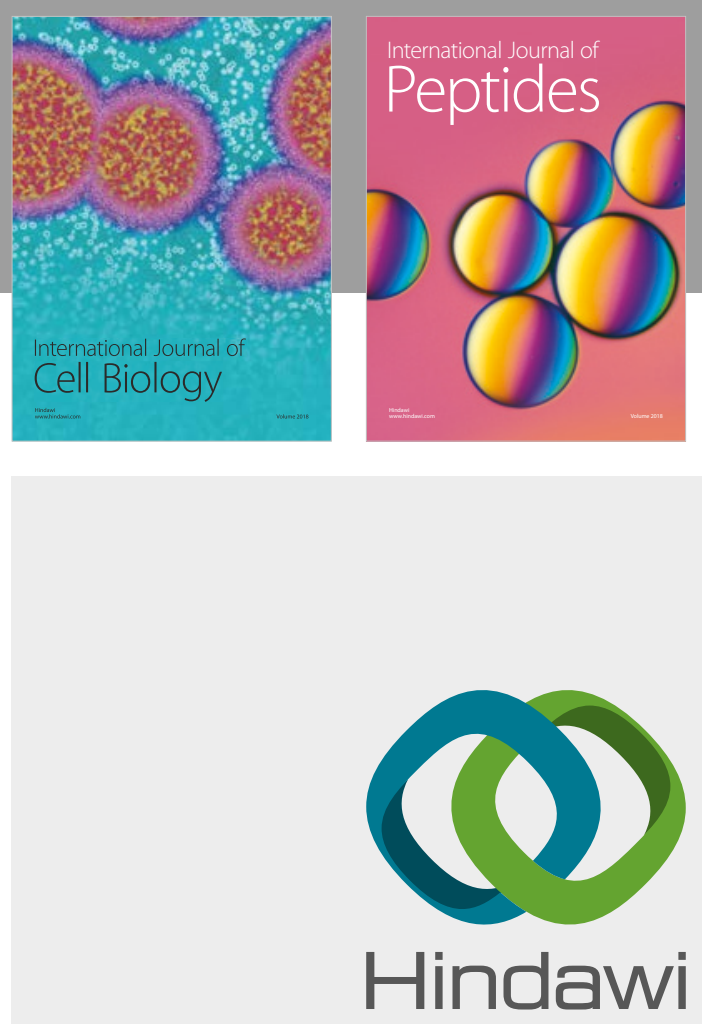

Submit your manuscripts at

www.hindawi.com
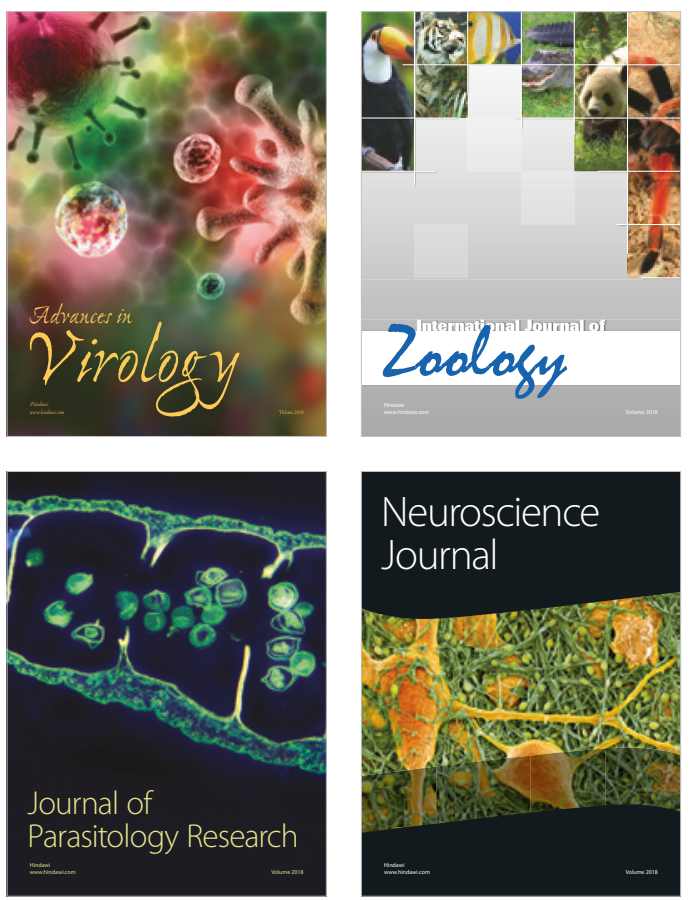
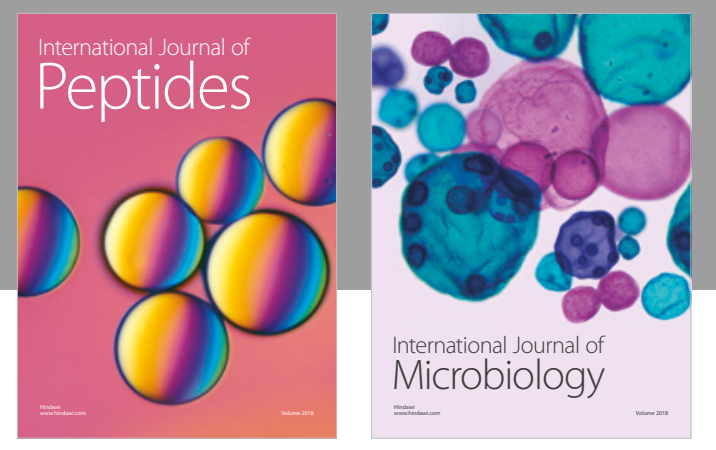

nternational Journal of Microbiology
Journal of
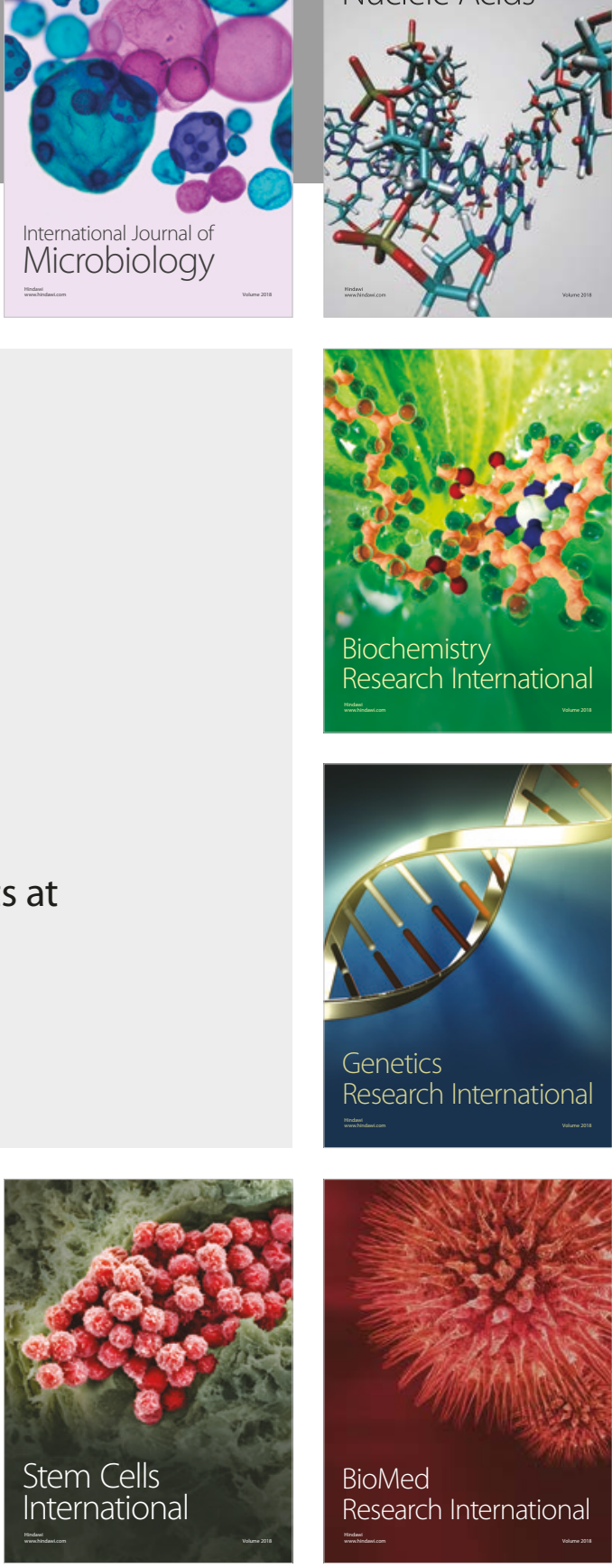
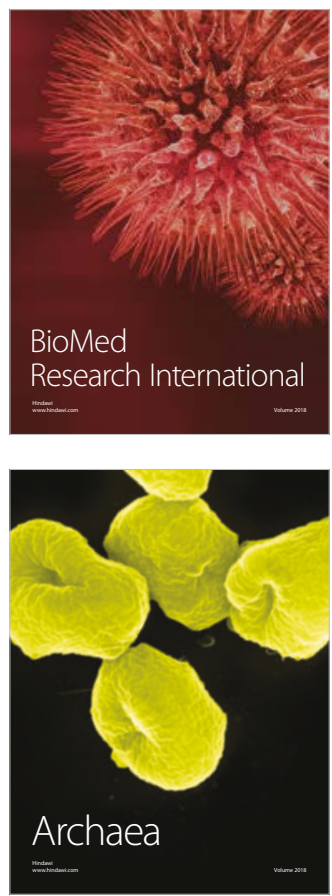